\title{
TRADITIONAL USES, PHYTOCHEMISTRY, AND PHARMACOLOGICAL ACTIVITIES OF AMLA WITH SPECIAL REFERENCE OF UNANI MEDICINE - AN UPDATED REVIEW
}

\author{
MASIHUDDIN ${ }^{1 *}$, JAFRI MA ${ }^{1}$, AISHA SIDDIQUI ${ }^{1}$, SHAHID CHAUDHARY ${ }^{2}$
}

${ }^{1}$ Department of Ilmul Advia, School of Unani Medical Education and Research, Jamia Hamdard, New Delhi. India. ${ }^{2}$ Department of Ilmul Saidla, School of Unani Medical Education and Research, Jamia Hamdard, New Delhi, India. Email: masihuddinkhan585@gmail.com

Received: 18 August 2018, Revised and Accepted: 01 November 2018

\section{ABSTRACT}

Emblica officinalis, commonly known as Amla belongs to family Euphorbiaceae, is widely used for medicinal purposes in Indian traditional system of medicine (Unani, Ayurveda, and Siddha). It is well known that all parts of Amla are useful in the treatment of various diseases. Various studies on Amla suggest that it has antiviral, antibacterial, and antifungal actions. It is one among those traditional plants, which have a long history of usage as a fruit and remedy. It is amazingly effective as natural antiaging drug. It is a very effectual plant in the treatment of acidity and peptic ulcer. According to Unani literature, it possesses nutritional as well as therapeutic values, and thus, it is one of the herbal nutraceuticals. Modern literature and research studies also prove its medicinal importance. Its fruit is used traditionally as an antioxidant, immunomodulator, antipyretic, analgesic, antitussive, anticancer, and gastroprotective. It is also useful in diarrhea, dysentery, diabetes, fever, headache, mouth ulcer, hair growth, scurvy, and constipation. Phytochemical studies on amla disclosed major chemical constituents including tannins, alkaloids, polyphenol, fatty acid, glycosides, phosphatides, vitamins, and minerals. Gallic acid, ellagic acid, phyllembein, and ascorbic acid are also found to be biologically effective. Various reports show the presence of catechol, $\beta$-carotene, flavonoids, pyrogallol, superoxide, and dismutase enzyme in Emblica fruit. In this review, an attempt is made to explore the complete information of E. officinalis including its phytochemistry and pharmacology.

Keywords: Antioxidant, Emblica officinalis, Unani.

(C) 2019 The Authors. Published by Innovare Academic Sciences Pvt Ltd. This is an open access article under the CC BY license (http://creativecommons. org/licenses/by/4. 0/) DOI: http://dx.doi.org/10.22159/ajpcr.2019.v12i2.29178

\section{INTRODUCTION}

From the ancient times, plants have been served as a key role for amelioration of humankind presenting as an exceptional source of natural drugs [1]. Herbal-derived medicine has made a large contribution to human health and well-being. The plants also act as a source of inspiration for the development of novel drug compounds, as plant-derived medicines have made large contributions to human health and well-being [2]. According to the World Health Organization (WHO), traditional medicine has established and proved to possess promotive, preventive, curative, and rehabilitative roles [3]. Approximately 80\% of world populations depend on traditional medicine for their primary health care and play an important role in the health-care system due to lesser side effect and better acceptability [4]. The WHO is promoting, encouraging, and facilitating the effectual use of conventional medicine for the health program in developing countries. Mankind started using plants products and plants successfully as a source for the treatment of disease and injuries as effective medicinal tool from the early days of civilization to modern age [5]. At ancient times, people were living long in comparision to present time because they were more habitual to nature. They used to work hard and were taking pure and natural edible things [6]. At present time, people are suffering from so many diseases because they are getting away from the natural way of life. We should adopt a correct method of diagnosis which could prevent the people from many diseases [7]. Research in medicinal plants has achieved a renewed focus recently. A large number of medicinal plants are available in the Indian traditional system of medicines (such as Unani, Ayurveda, and Siddha) and one of them is amla or Indian gooseberry, also known as Emblica officinalis Linn. [8]. It is herbal medicine that inspires the herbalist due to its renowned medicinal and nutritional effects [9]. E. officinalis is a precious gift of nature to mankind. It is a wonder herb and indispensable part of the Unani system with amazing medicinal qualities. It is known as "Divya" in Ayurveda which literally means fruit of heaven or nectar fruit. It is also called as the sustainer or the fruit where the Goddess of prosperity resides [10]. According to believe in ancient Indian mythology, it is the first tree to be created in the universe [11]. It belongs to family Euphorbiaceae. It is an angiosperm of the order Euphorbiales and family Euphorbiaceae. The tree is small to medium in size, deciduous, reaching 8 to $18 \mathrm{~m}$ in height. The leaves are simple, subsessile while flowers are greenish-yellow. The fruit are spherical with six obscure vertical furrows [8,12]. It is native to tropical and Southeast Asia, particularly found in Central or Southern India, Pakistan, Bangladesh, Sri Lanka, Malaya, Southern China, and Mascarene Islands. It has been grown in India for more than 3500 years. In eastern and western hills of India, three species, namely Phyllanthus emblica, Phyllanthus acidus, and Phyllanthus indofischeri, are commonly found [13]. In traditional system of medicine, amla is one of the most extensively used plants. According to Unani literature, it is used alone or in combination with other drugs as compound formulation such as Itrifalat, Jawarish Amla, Jawarish shahi, and Anushdaru [14]. having a function of Muqawwe dimagh, (Brain tonic) Muqawwe basar, (Eye tonic) jali, (Detergent) Kasire Riyah, (Carminative) Mohallil (Antiinflammatory) etc., [14-17]

Amla has undertaken preliminary research demonstrating in vitro as antiviral and antimicrobial properties [18]. Emblica fruit is reported to have anti-inflammatory [19,20], analgesic [3], antioxidant [21], antihyperlipidemic [22], hypolipidemic [23], anticancer [24,25], hepatoprotective [26,27], apoptogenic [28], antipyretic [3], antibacterial [29], and antidepressant activities [30].

\section{Distribution and habitat}

The plant is small or middle-sized deciduous tree with smooth greenish exfoliated bark commonly found throughout the greater part of India, Ceylon, Malaya, and China [14,15,31] reaching a height up to $45 \mathrm{ft}$ on the hills. It is often cultivated in gardens and home yards [31]. It is usually propagated by seeds or may also be propagated vegetatively by budding, cutting, and inarching. The plant is sensitive to frost and drought. The tree coppices well and coppices shoots grow vigorously. Flowers usually appear in the hot season and fruit ripen during the 
following winter. In some parts of Madaras, flowering is observed in July and February, but the second bloom does not yield a sizable crop [31].

Taxonomical classification (United States Department of Agriculture) [32]

\begin{tabular}{ll}
\hline Kingdom & Plantae \\
\hline Subkingdom & Tracheobionta \\
Superdivision & Spermatophyta \\
Division & Magnoliophyta \\
Class & Magnoliopsida \\
Subclass & Rosidae \\
Order & Euphorbiales \\
Family & Euphorbiaceae \\
Genus & Emblica L. \\
Species & Officinalis \\
\hline
\end{tabular}

\section{Vernacular names $[14,31,33-35]$}

\begin{tabular}{ll}
\hline Arabic & Ambliy, Amlaj \\
Persian & Amelah, Amuleh \\
Urdu & Anwala, Aamla \\
Bengali & Ambolati, Amla, Amlakim, Amlati, Anulati, Anulah, \\
& Anvurah, Anwerd, Aonla, Aunra \\
English & Emblic, myrobalan tree, Indian goose \\
Gujarati & Amali, Ambala, Ambri, Amla, Bhoza, Bhozaamali \\
Hindi & Amalaki, Amla, Amlika, Anola, Anuli, Anvula, Anvurah, \\
& Aunra, Daula \\
Kannada & Amalaka, Nelli \\
Marathi & Anvala, Aonli, Avola, Bhuiawali \\
Oriya & Amlaki \\
Punjabi & Ambal, Ambli, Ambul, Amla, Aonla \\
Sanskrit & Adiphala, Amalaki, Amraphala, Amrita, Bahuphali, \\
& Dhatriphala, Karshaphala, Triphala \\
Tamil & Amalagam, Andakaram, Indul, Kattunelli, Perunelli, Nelli, \\
& Tattri, Sivottam \\
Telugu & Amalakamu, Amalaki, Nelli, Pullayusirika, Triphalamu, \\
& Usirika, Usirikaya, Usirki \\
\hline
\end{tabular}

\section{Morphology}

\section{Macroscopic characteristics}

The leaves are subsessile, $10-13 \mathrm{~mm} \times 2.5-3 \mathrm{~mm}$, closely set along the branchlets, distichous, light green, glabrous, narrowly linear, resembling pinnate leaves $[14,15]$ The fruit is $1.3-1.6 \mathrm{~cm}$ in diameter, fleshy, globose with 6 obscure vertical furrows, green, and it tends to light yellow or brick-red color when mature [15,31]. Flower is greenish-yellow, refrigerant, and aperients, in axillary fascicles on the leaf-bearing branchlets, often on the naked portion below the leaves, with fimbriate bracts at the base. Male flowers are numerous with short slender pedicels while female flowers few subsessile. Disk is three-celled, styles connate at the base. The seed is acrid, sweet [15].

\section{Microscopic characteristics}

The transverse section of the leaf shows a bifacial structure. The upper epidermal cell is single-layered, tangentially elongated cells covered by thin cuticle. Mesophyll is differentiated into palisade and spongy layer. Palisade cells are single layered, vertically elongated and have a length of approximately 44-50 u. Spongy parenchyma consists of 5-6 layer of parenchymatous cells with many intracellular spaces. Some cells contain rosette-shaped crystals of calcium oxalate having diameter 18-22 u. Lower epidermis is characterized by the presence of paracytic type of stomata. All the cells give a positive test for tannin. No trichomes or hairs present on either surface. Transverse section through the midrib region shows collateral bundles in the center with xylem toward ventral side and phloem toward dorsal side. Crescent-shaped arms of lignified fibers present below the vascular bundle [14].

\section{Temperament (Mijaz)}

- $\quad$ Cold ${ }^{1}$ and Dry $^{2}[14,16,17]$

- Cold $^{2}$ and $\operatorname{Dry}^{4}[34]$

- $\quad$ Cold $^{2}$ and Dry $^{3}[35]$

Parts used

- Dry and fresh fruit, leaves, root, bark, flower, fruit [17]

- Seed [14].

Doses

- $10.5 \mathrm{~g}[16]$

- $\quad 5-10 \mathrm{~g}[14]$

- $6 \mathrm{~g}[34]$

\section{Adverse effects (Muzir asrat)}

It produces constipation and colic. It has harmful effect on bladder [17] and spleen [34].

\section{Substitutes (Badal)}

Halaila Kabuli (Terminalia chebula), Halaila siyah (Terminalia chebula), Asaroon (Valeriana wallichii) [17], Halaila Kabuli (Terminalia chebula) [34].

\section{Correctives (Musleh)}

Asal (Honey) [36], Almond oil, (Prunus amygdalus) Ishq pecha (Ipomea quamoclit), Balchhad, Sharbat injeer [17]. Aab lablab [16]. Asal (Honey), Almond oil. (Prunus amygdalus) [34].

\section{Compound formulations}

Itrifal muqawwi dimagh, Itrifal kishneezi, Jawarish Amla, Jawarish Shahi, Majoon najah, and Anashdaru [14].

\section{Pharmacological actions}

- Mulayin (laxative) [15]

- Mudirre baul (diuretic) [15]

- Jali (detergent) [16]

- Qabiz (constipative) [15]

- Mobarrid (cooling) [15]

- Kasire riyah (carminative) [15]

- Man qai (antiemetic) [17]

- Daf Khafqan (palpitation) [16]

- Daf Humma (antipyretic) [15]

- Mohallil (anti-inflammatory) $[15,16]$

- Muharrik-e-Baah (sexual stimulant) [16]

- Muqawwi bah (aphrodisiac) [15]

- Mulattif (demulcent) [16]

- Muqawwi aam (general tonic) [16]

- Muzaiyade mani (semen producing) [17]

- Muqawwi basar (vision improving) $[16,17]$

- Muqawwi dimagh (brain tonic) $[14,33,37]$

- Muqawwi lissa (gum tonic) [17]

- Muqawwi jigar (liver tonic) [17]

- Musakkin atash (relieving excess thrust) [17]

- Habis e ishal (antidiarrhoeal) [17]

- Mufarrah Muqawwi qalb (cardiac exhilarant and tonic) [17]

- Musaffi dam (blood purifier) $[14,17]$

- Muqawwi meda (stomachic) $[17,33,37,38]$

- Musawwade shar (hair blackening) $[16,17,39]$

- Mushtahi (appetizer) $[15,17]$

- Habis wa Qabiz (astringent) $[14,15,17,33,36,37,39]$

- Taqwiate Hifz (memory enhancing) [16,17]

- Zof ama (weakness of intestine) $[16,17]$.

\section{Therapeutic uses}

- Khafqan (palpitation) $[16,17,39,40]$

- Baul fil ferash (nocturnal enuresis) $[16,17]$

- Bayaz chashm (opacity) [16]

- Bawasir (piles) [15-17,39] 
- $\quad$ kasrat loaab (excessive salivation) [17]

- Sailanur raham (leucorrhea) $[15,17]$

- Qai (vomiting) [15-17]

- Sara (epilepsy) [17]

- Nazfud Dam (hemorrhage) $[16,39]$

- Suzaak (gonorrhoea) [17]

- Bilkhora (alopecia) [14,17]

- Aphthous ulcer [14]

- Hirqat baul (burning micturation) $[15,16]$

- Nisyan (amnesia) [16,39]

- Ashob chashm (conjunctivitis) [31,39]

- Hamuzat medi (hyperacidity) [16]

- Sual (cough) $[15,17,41]$

- Sue hazm (indigestion) [14]

- Qabz (constipation) [15-17,35,39]

- Atash (excessive thirst) [15-17]

- Zof qalb wa dimagh (weakness of the heart and dimagh) $[16,17,35,40]$

- Daul haiya (hair falling) [16,17]

- Nazfuddam (hemorrhage) $[16,17,39]$

- Ishaal(diarrhea) $[14,16,17,39,40]$

- Surkhbada (erysipelas) $[15,41]$

- Nakseer (epistaxis) [16,17,42]

- Shabkori (night blindness) [43]

- Zaheer (dysentry) $[14,16,17,44]$

- Faqruddam (anemia) [15,44-46]

- Malinkholia wa Saudawi Amraaz (melancholia and black bile disorders) $[16,17]$

- Falij (paralysis) [16,17]

- Zof ishteha (lack of appetite) $[16,17]$

- Yarqaan (jaundice) $[16,17,41,45-48]$

- Kasrat loab (excessive salivation) $[16,17]$

- Laqwah (facial paralysis) [61,17]

- Juzam (leprosy) $[15,41]$

- Muqallil baul (anuria) [15]

- Margazeede (snakebite) [15]

- Suzak (gonorrhea) [15]

- Leucorrhoea $[15,17,41]$

- Hair falling and graying of hair $[16,17]$

\section{Phytochemical constituents}

The active ingredient that has significant pharmacological action inamla is designated by Indian scientist as "Phyllemblin" [10].

The fruit is rich in Vitamin C, quercetin, phyllaemblic compounds, gallic acid, flavonoids, pectin, ellagic acid, terpenoids, alkaloids, flavonoids, tannins, and glucose and its molecule [10,31].

The root contains ellagic acid and lupeol [18].

The seeds yield a fixed oil, phosphatides, and a small quantity of essential oil. The fixed oil yields $16 \%$ and has the following physical and chemical characteristics: Acid insoluble values (12.7\%); acetyl value 2.03; unsaponifiable matter $3.81 \%$; sterol $2.70 \%$; saturated fatty acid 7\%; linolenic acid (8.78 \%); linoleic (44\%); oleic (28.40\%); steric $(2.15 \%$; palmitic $(3.0 \%)$; and myristic $(1.0 \%)$, and lipolytic enzymes are present in the seed $[10,18,31]$. The phytochemicals of this plant include hydrolysable tannins (emblicanin A, emblicanin $\mathrm{B}$, punigluconin, and pedunculagin), flavonoids (kaempferol3-0-alpha-L-(6" methyl) rhamnopyranoside and kaempferol-3-0alpha-L-(6" ethyl) amnopyranoside), alkaloids (phyllantidine and phyllantine), fallic acid, ellagic acid, 1-0-galloyl-beta-D-glucose, 3,6-di-0-galloyl-D-glucose, chebulinic acid, quercetin, chebulagic acid, and corilagin together with isostrictinnin, which were isolated from the fruit of P. emblica. A new acylated glucoside was isolated from the methanolic extract of the leaves of $P$. emblica. Their structures were named as apigenin 7-0-(6"-butyryl-beta)glucopyranoside, along with four known compounds, namely gallic acid, methyl gallate, 1,2,3,4,6-penta-Ogalloylglucose, and luteolin4 'One ohesperiodoside. The seed of P. emblica contains fixed oil, phosphatides, and small quantity of essential oil [10].

The leaves contain gallic acid, ellagic acid, chebulic acid, chebulinic acid, chebulagic acid, a gallantonic called amlic acid, and alkaloids (phyllantidine and phyllantine) [18].

The bark contains leukodelphinidin [10], tannin, and proanthocyanidin [18].

\section{Pharmacological studies}

- Analgesic activity [3]

- Memory enhancing activity [49]

- Anti-inflammatory activity $[3,19,20]$

- Antimicrobial activity $[18,50,51]$

- Antioxidant activity [13,21,52-60]

- Antibacterial activity $[29,56,61]$

- Antipyretic activity [3]

- Antitumor activity [55]

- Antidepressant activity $[9,30]$

- Antiproliferative activity [21]

- Anticancer activity $[25,26,55,62]$

- Antidiarrheal and spasmolytic activity $[63,64]$

- Antidiabetic activity [22,65-67]

- Antifungal activity $[12,68,69]$

- Antiviral activity $[24,26,70]$

- Immunomodulatory activity [71-73]

- Gastroprotective activity [74]

- Hepatoprotective activity $[26,27,75,76]$

- Nephroprotective activity [77]

- Oxidative stress activity [78]

- Antiepileptic activity [79]

- Dyslipidemic activity [80]

- Protective activity [81]

- Apoptogenic activity [28]

- Antiproliferative activity [21]

- Hypercholesterolemic activity [82]

- Anticandidal activity [83]

- Diuretic activity [84]

- Venom neutralizing activity $[85,86]$

- Larvicidal and mosquitocidal activity [87]

- Antidandruff and hair strengthening activity [88]

- Antihypertensive activity [89]

- Chondroprotective activity [90]

- Cytotoxic activity [51]

- Antiulcer activity [91].

\section{CONCLUSION}

The fitness and healthy look have become a religion for the present generation. Research on medicinal plant has achieved a new recommence in this era. Plant-based system of medicine being natural does not pose a serious problem. E. officinalis has an important position in the Unani System of Medicine. Due to its strong antioxidant and biological properties, It protects from many diseases due to its strong antioxidant and biological properties as it contains highest amount of Vitamin C as well as essential nutrients. In this review, we tried to make a summary on traditionally and scientifically proven uses of amla. Although amla has a various medicinal properties since ages, there is a colossal necessity to evident and explore its medicinal values at molecular levels with the help of latest techniques and biotechnological tools. It is considered to be safe herbal medicine without any adverse effect, so it can be concluded that India gooseberry is a traditionally and clinically proven fruit for both its efficacy and application.

\section{AUTHORS' CONTRIBUTIONS}

Masihuddin: Work design, data collection, analysis, drafting article, writing manuscript, and critical revision of the article. Prof. M.A Jafri: Design of the work, data analysis, critical revision of the article, and final approval of the version to be published. Dr. Aisha 
Siddiqui: Data analysis and critical revision. Dr. Shahid Chaudhary: Data analysis and critical revision.

\section{CONFLICTS OF INTEREST}

The authors declare that there are no conflicts of interest associated with this article.

\section{REFERENCES}

1. Rubaiyat $\mathrm{H}$, Islam $\mathrm{N}$, Islam $\mathrm{R}$. Phytochemistry, pharmacological activities and traditional uses of Emblica officinalis: A review. Int Curr Pharm J 2016;5:14-21.

2. Dasi S, Borah M, Ahmed S. Antibacterial activity of the ethanolic extract of leaves of Citrus maxima (Burm.) Merr. On Escherichia coli and Pseudomonas aeruginosa. Asian J Pharm Clin Res 2013;6:136-9.

3. Mradu G, Dalia B, Anup M. Studies of anti-inflammatory, antipyretic and analgesic effects of aqueous extract of traditional herbal drug on rodents. Int Res J Pharm 2013;4:113-20.

4. Sharma $\mathrm{D}$, Bhatt $\mathrm{S}$. A comprehensive review on ulcer healing potential of medicinal plants. Int J Pharm Pharm Sci 2014;10:3-11.

5. Jain R, Pandey R, Mahant R N, Rathore DS. A review on medicinal importance of Embelica officinalis. Int J Pharm Sci Res 2015;6:72-84.

6. Mirunalini S, Mahant VV, krishnaveni M. Amla: A novel Ayurvedic herb as a functional food for health benefits - A mini review. Int J Pharm Pharm Sci 2013;5:1-4.

7. Reddy MP, Kavya B, Rao VR, Shantha TR, Kumar RK, Venkateshwarlu G, et al. Therapeutic uses of flowers - Leads from traditional system of medicine. Int J Herbal Med 2015;3:12-20.

8. Dasaroju S, Gottumukkala KM. Current trends in the research of Embelica officinalis (Amla) a pharmacological perspective. Int J Pharm Sci Rev Res 2014;24:150-9.

9. Yadav V, Duvey B, Sharma S, Devi B. Amla (Emblica officinalis) - Medicinal food and pharmacological activity. Int J Pharm Chem Sci 2014;3:616-9.

10. Singh E, Sharma S, Pareek A, Dwivedi J, Yadav S, Sharma S. Phytochemistry, traditional uses and cancer chemopreventive activity of amla (Phyllanthus emblica). The sustainer. J Appl Pharm Sci 2011;2;176-83.

11. Khan KH. Roles of Emblica officinalis in medicine - A review. Bot Res Int 2009;2;218-28.

12. Nath A, Raghunatha P, Joshi SR. Diversity and biological activities of endophytic fungi of Emblica officinalis, an ethnomedicinal plant of India. Mycobiology 2012;40:8-13

13. Agte V, Bhute R, Pathare $\mathrm{P}$, Nilegaonkar S. Factors influencing the antioxidant potential of amla and its products. Br J Pharm Res 2014;4;2575-84

14. Ministry of Health and Family Welfare, Government of India. Standardization of Single Drugs of Unani Medicine. CCRUM, New Delhi; Ministry of Health and Family Welfare, Government of India; 2006. p. 1-4

15. Kirtikar KR, Basu BD. Indian Medicinal Plants. Dehradun: International Book Distributers; 1996. p. 2220-2.

16. Azam MK. Muheet Azam (Urdu Translation by CCRUM). New Delhi: Institutional Area; 2012. p.213-5.

17. Ghani MN. Khazaenul Advia. Lahore: Sheikh Muhammad Basheer and Sons; 1994. p. 407-11.

18. Jahan N, Akter S. Assessment of the antimicrobial activity of the ethanolic extract of Phyllanthus emblica in combination with different classes of antibiotics against single and multidrug resistant strains. J Pharm Phytochem 2015;4:142-55.

19. Muthuraman A, Sood S, Singla SK. The antiinflammatory potential of phenolic compounds from Emblica officinalis L. In rat. Inflammopharmacology 2011;19:327-34.

20. Golechha M, Sarangal V, Ojha SS, Bhatia J, Dharmveer SA. Antiinflammatory effect of Emblica officinalis in rodent models of acute and chronic inflammation: Involvement of possible mechanisms. Int $\mathrm{J}$ Inflam 2014;6:1-6

21. Luo W, Zhao M, Yang B, Ren J, Shen G, Rao G. Antioxidant and antiproliferative capacities of phenolics purified from Phyllanthus emblica L. fruit. Food Chem 2011;126:277-82.

22. Tirgar PR, Shah KV, Patel VP, Desai TR, Goyal RK, Investigation into mechanism of action of anti-diabetic activity of Emblica officinalis on streptozotocin induced Type I diabetic rat. Res J Pharm Biol Chem Sci 2010;1:556-75.

23. Santoshkumar J., Manjunath S., Pranavkumar MS. A study of anti- hyperlipidemia, hypolipedimic and anti-atherogenic activity of fruit of Emblica officinalis (Amla) in high fat fed albino Rats. Int J Med Res Health Sci 2013;2:70-7.

24. Liu G, Xiong S, Xiang YF, Guo CW, Ge F, Yang CR, et al. Antiviral activity and possible mechanisms of action of pentagalloylglucose (PGG) against influenza a virus. Arch Virol 2011;156:1359-69.

25. Zhao T, Sun Q, Marques M, Witcher M. Anticancer properties of Phyllanthus emblica (Indian gooseberry). Oxid Med Cell Longev 2015;2015:950890.

26. Husain S, Anzar A, Ahmed S, Quamri A, Khan AM. Hepatoprotective, anticancer and antiviral effects of Bhui Amla in Unani medicine: An overview. J Med Plants Stud 2014;2:50-2.

27. Srirama R, Deepak HB, Senthilkumar U, Ravikanth G, Gurumurthy BR, Shivanna MB, et al. Hepatoprotective activity of Indian Phyllanthus. Pharm Biol 2012;50:948-53.

28. Penolazzi L, Lampronti I, Borgatti M, Khan MT, Zennaro M, Piva R, et al. Induction of apoptosis of human primary osteoclasts treated with extracts from the medicinal plant Emblica officinalis. BMC Complement Altern Med 2008;8:59.

29. Sharma S, Bharose R, Agarawal SK, Pal K. Antibacterial activities against different selective mic extraction of Amla. Int J Pharm Prof Res 2012;3:587-91.

30. Pawar DB, Marathe PA, Rege NN. Antidepressant activity of aqueous extracts of fruits of Terminalia chebula and Phyllanthus emblica in behavioural models of depression. Involvement of monoaminergic system. Int J Pharm Pharm Sci 2014;6:615-20.

31. CSIR. The Wealth of India. New Delhi: CSIR; 2003. p. 168-70.

32. USDA.Availablefrom:http://www.plants,usda.gov/core/profile?symbol =PHEM2. [Last cited on 2014 Oct 20].

33. Nadkarni K. The Indian Materia Medica. Bombay: A.K Nadkarni Publishers; 1989. p. 480-4.

34. Nabi MG. Makhzanul Mufradat wa Murakkabad (Maroof be Khawasul Advia), CCRUM, New Delhi: Department of Ayush, Ministry of Health and Family Welfare. Goverment of India; 2004.

35. Hakeem M. Bustanul Mufradat. New Delhi: Ajaz Publishing House; 2011. p. 72.

36. Baitar I. Aljame Li Mufradat al Advia wal Aghzia, (Urdu translation). CCRUM, New Delhi: Department of Ayush, Ministry of Health and Family Welfare. Goverment of India; 2017. p. 129-31.

37. Singh M, Panda H. Medicinal Herbs with Their Formulations. New Delhi: Daya Publishing House; 2005. p. 261.

38. Kabirruddin MH. Makhzanul Mufridat Al Maroof Khawasul Advia. New Delhi: Ajaz Publishing House; 2000. p. 55.

39. Imran MU. Tanqeehul Mufradat. New Delhi: Ajaz Publishing House; 2008. p. 18-9.

40. Kabirruddin M. Makhzanul Mufridat Yani Kitabul Advia. New Delhi: Idara Kitabush Shifa; 2007. p. 49-50.

41. Sala AV. Indian Medicinal Plants a Compendium of 500 Species, Madras: Orient Longman Ltd.; 1997. p. 256-7.

42. Ashraf MH. Makhzanul Mufridat Ma Murakkabat Wa Khawasul Advia. New Delhi: Idara Taraqqi Urdu Limited.; 2016

43. Ambasta SP. The Useful Plants of India. New Delhi: CSIR; 1992. p. 195.

44. Kokate CK, Purohit AP, Gokhale SB. Pharmacognosy. Pune: Nirali Prakashan; 2006. p. 262-3.

45. Evans IC. Trease and Evans Pharmacognosy. London: WHO; 1997. p. 253.

46. Dymock W, Warden CJ, Hooper D. Pharmacographia Indica, A History of the Principal Drugs of Vegetable Origin. New Delhi: Srishti Book Distributers; 2005. p. 261-3.

47. Chopra RN, Nayar SL, Chopra IC. Glossary of Indian Medicinal Plants. New Delhi: CSIR; 1956. p. 106-7.

48. Asolkar LV, Kakkar KK, Chakre OJ. Glossary of Indian Medicinal Plants with Active Principles. New Delhi: CSIR; 1992. P. 291-2.

49. Vasudevan M, Parle M. Memory enhancing activity of anwala churna (Emblica officinalis Gaertn.): An Ayurvedic preparation. Physiol Behav 2007;91:46-54.

50. Sharma K, Sharma P, Srivastav R, Srivastava A, Sharma D. Pharmacological study of amalaki with special reference to its antimicrobial action. Int J Appl Pharm Res 2017;5:93-6.

51. Rahman S, Akbor MM, Howlader A, Jabbar A. Antimicrobial and cytotoxic activity of the alkaloids of amlaki (Emblica officinalis). Pak J Biol Sci 2009; 12:1152-5.

52. Mehrotra S, Jamwal R, Shyam R, Meena DK, Mishra K, Patra R, et al. Anti-helicobacter pylori and antioxidant properties of Emblica officinalis pulp extract: A potential source for therapeutic use against gastric ulcer. J Med Plants Res 2011;5:2577-83. 
53. Shukla V, Vashistha M, Singh SN. Evaluation of antioxidant profile and activity of amlaki (Emblica officinalis), spirulina and wheat grass. Indian J Clin Biochem 2009;24:70-5.

54. Khopde SM, Priyadarsini KI, Mohan H, Gawandi VB, Satav JG, Yakhmi JV, et al. Characterizing the antioxidant activity of amla (Phyllanthus emblica) extract. Curr Sci 2001;81:185-90.

55. Sumalatha D. Antioxidant and antitumor activity of Phyllanthus emblica in colon cancer cell lines. Int J Curr Microbiol Appl Sci 2013;2:189-95.

56. Sripanidkulchai B, Fangkrathok N, Antioxidant, antimutagenic and antibacterial activities of extracts from Phyllanthus emblica branches Songklanakarin. J Sci Technol 2014;36:669-74.

57. Pundareekaksha RP. Antioxidant effect of triphala - Critical review. J Ayurveda Integr Med Sci 2017;2:213-9.

58. Hazra B, Sarkar R, Biswas S, Mandal N. Comparative study of the antioxidant and reactive oxygen species scavenging properties in the extracts of the fruits of Terminalia chebula, Terminalia belerica and Emblica officinalis. BMC Complement Altern Med 2010;10:20.

59. Mathew M, Subramanian S. In vitro screening for anti-cholinesterase and antioxidant activity of methanolic extracts of Ayurvedic medicinal plants used for cognitive disorders. PLoS One 2014;9:e86804.

60. Vani T, Rajani M, Sarkar S, Shishoo CJ. Antioxidant properties of the Ayurvedic formulation triphala and its constituents. Int J Pharm 1997;35:313-7.

61. Bag A, Bhattacharyya SK, Bharati P, Pal NK, Chattopadhyay RR. Evaluation of antibacterial properties of Chebulic myrobalan (fruit of Terminalia chebula Retz.) extracts against methicillin resistant Staphylococcus aureus and trimethoprim-sulphamethoxazole resistant uropathogenic Escherichia coli. Afr J Plant Sci 2009;3:25-9.

62. Baliga MS, Dsouza JJ. Amla (Emblica officinalis Gaertn), a wonder berry in the treatment and prevention of cancer. Eur J Cancer Prev 2011;20:225-39.

63. Mehmood MH, Siddiqi HS, Gilani AH. The antidiarrheal and spasmolytic activities of Phyllanthus emblica are mediated through dual blockade of muscarinic receptors and ca2+ channels. J Ethnopharmacol 2011;133:856-65.

64. Perianayagam JB, Narayanan S, Gnanasekar G, Pandurangan A, Raja S, Rajagopal K, et al. Evaluation of antidiarrheal potential of Emblica officinalis. Pharm Biol 2005;43:373-7.

65. Krishnaveni M, Mirunalini S, Karthishwaran K, Dhamodharan G. Antidiabetic and antihyperlipidemic properties of Phyllanthus emblica Linn. (Euphorbiaceae) on streptozotocin induced diabetic rats. Pak J Nutr 2010;9:43-51.

66. Kalekar SA, Munshi RP, Bhalerao SS, Thatte UM. Insulin sensitizing effect of 3 Indian medicinal plants: An in vitro study. Indian J Pharmacol 2013;45:30-3.

67. Suryanarayana P, Saraswat M, Petrash JM, Reddy GB. Emblica officinalis and its enriched tannoids delay streptozotocin-induced diabetic cataract in rats. Mol Vis 2007;13:1291-7.

68. Bobbarala V, Katikala PK, Chandrasekhar NK, Penumajji S. Antifungal activity of selected plant extracts against phytopathogenic fungi Aspergillus niger. Indian J Sci Technol 2009;2:87-90.

69. Amala EV, Jeyaraj M. Determination of antibacterial, antifungal, bioactive constituents of triphala by FT-IR and GC-MS analysis. Int J Pharm Pharm Sci 2014;6:123-6.

70. Wang YF, Wang XY, Ren Z, Qian CW, Li YC, Kaio K, et al. Phyllaemblicin B inhibits coxsackie virus B3 induced apoptosis and myocarditis. Antiviral Res 2009;84:150-8.

71. Srikumar R, Jeya Parthasarathy N, Sheela Devi R. Immunomodulatory activity of triphala on neutrophil functions. Biol Pharm Bull 2005;28:1398-403.

72. Sai Ram M, Neetu D, Yogesh B, Anju B, Dipti P, Pauline T, et al. Cyto-protective and immunomodulating properties of amla (Emblica officinalis) on lymphocytes: An in-vitro study. J Ethnopharmacol 2002;81:5-10.
73. Saraphanchotiwitthaya A, Sripalakit P. Immunomodulatory effect of different proportions of the herbal mixture in triphala on human T- lymphocytes (molt-4). Int J Pharm Pharm 2015;7:282-8.

74. Al-Rehaily AJ, Al-Howiriny TA, Al-Sohaibani MO, Rafatullah S. Gastroprotective effects of 'amla' Emblica officinalis on in vivo test models in rats. Phytomedicine 2002;9:515-22.

75. Deori C, Das S, Bordoloi SK. Study of hepatoprotective activity of Embelica officinalis (Amla) in albino rats. J Evid Based Med Healthc 2017;4:3298-01.

76. Adewusi EA, Afolayan AJ. A review of natural products with hepatoprotective activity. J Med Plants Res 2010;4;1318-34

77. Malik S, Suchal K, Bhatia J, Khan SI, Vasisth S, Tomar A, et al. Therapeutic potential and molecular mechanisms of Emblica officinalis Gaertn in countering nephrotoxicity in rats induced by the chemotherapeutic agent cisplatin. Front Pharmacol 2016;7:350.

78. Yokozawa T, Kim HY, Kim HJ, Tanaka T, Sugino H, Okubo T, et al. Amla (Emblica officinalis gaertn.) attenuates age-related renal dysfunction by oxidative stress. J Agric Food Chem 2007;55:7744-52.

79. Golechha M, Bhatia J, Ojha S, Arya DS. Hydroalcoholic extract of Emblica officinalis protects against kainic acid-induced status epilepticus in rats: Evidence for an antioxidant, anti-inflammatory, and neuroprotective intervention. Pharm Biol 2011;49:1128-36.

80. Antony B, Benny M, Kaimal TN. A pilot clinical study to evaluate the effect of Emblica officinalis extract (Amlamax ${ }^{\mathrm{TM}}$ ) on markers of systemic inflammation and dyslipidemia. Indian $\mathrm{J}$ Clin Biochem 2008;23:378-81.

81. Jindal A, Soyal D, Sharma A, Goyal PK. Protective effect of an extract of Emblica officinalis against radiation-induced damage in mice. Integr Cancer Ther 2009;8:98-105.

82. Kim HJ, Yokozawa T, Kim HY, Tohda C, Rao TP, Juneja LR, et al. Influence of amla (Emblica officinalis gaertn.) on hypercholesterolemia and lipid peroxidation in cholesterol-fed rats. J Nutr Sci Vitaminol (Tokyo) 2005;51:413-8.

83. Thaweboon B, Thaweboon S. Effect of Phyllanthus emblica linn. On candida adhesion to oral epithelium and denture acrylic. Asian Pac J Trop Med 2011;4:41-5.

84. Hullatti KK, Sharada MS, Kuppasth IJ. Studies on diuretic activity of three plants from Menispermaceae family. Der Pharm Sin 2011;2:129-34

85. Sarkhel S, Chakravarty AK, Das R, Gomes A. Snake venom neutralising factor from the root extract of Emblica officinalis Linn. Orient Pharm Exp Med 2011;11:25-33.

86. Alam MI, Gomes A. Snake venom neutralization by Indian medicinal plants (Vitex negundo and Embelica officinalis) root extract. J Ethnopharm 2003;86:75-80.

87. Hasan R, Islam N, Islam R. Phytochemistry, pharmacological activities and traditional uses of Emblica officinalis: A review. Int Curr Pharm J 2016;5:14-21.

88. Nikhil NA. Preparation and evaluation of shampoo powder containing herbal ingredients. Asian J Pharm Clin Res 2015;8:266-70.

89. Bhatia J, Tabassum F, Sharma AK, Bharti S, Golechha M, Joshi S, et al. Emblica officinalis exerts antihypertensive effect in a rat model of DOCA-salt-induced hypertension: Role of (p) eNOS, NO and oxidative stress. Cardiovasc Toxicol 2011;11:272-9.

90. Sumantran VN, Kulkarni A, Chandwaskar R, Harsulkar A, Patwardhan B, Chopra A, et al. Chondroprotective potential of fruit extracts of Phyllanthus emblica in osteoarthritis. Evid Based Complement Alternat Med 2008;5:329-35.

91. Rajeshkumar NV, Therese M, Kuttan R. Emblica officinalis fruits afford protection against experimental gastric ulcers in rats. Pharm Biol 2001;39:375-80. 